\title{
Validation of Bahasa Malaysia Version of Psychological Mindedness in a University Population
}

\author{
Mohd Amiruddin, Mohd Kassim; Nicholas Tze Ping, Pang; Wendy Diana, Shoesmith; Mathias Wen Leh, \\ Tseu; Ervina Abbylen, Malindoi; Yin Xin, Yeoh \\ Faculty of Medicine and Health Sciences, Universiti Malaysia Sabah, Malaysia
}

\section{ABSTRACT}

INTRODUCTION: Psychological mindedness concept is widely accepted to be significantly correlated to psychological strength and mental health. There are multiple scales that attempted to measure psychological mindedness objectively, with the most recent one being Balanced Index of Psychological Mindedness (BIPM). Psychological mindedness is an area of interest in psychiatry and psychology in Malaysia. Hence, this study aims to validate the Bahasa Malaysia Version of Balanced Index of Psychological Mindedness (BIPM-M). MATERIALS AND METHODS: The 14-items scale was translated according to World Health Organization guidelines. 141 participants were recruited from the university population. Participants were required to fill the basic demographic information, as well as Bahasa Malaysia version of Balanced Index of Psychological Mindedness, and two other scales, namely Mindful Awareness Attention Scale (MAAS), and Acceptance and Action Questionnaire-II Scale (AAQ-II). RESULTS: BIPM-M showed excellent internal consistency with Cronbach $\alpha$ of 0.87 . As per the original BIPM, the Bahasa Malaysia version also suggested two factor structures in this scale. BIPM-M was significantly correlated with AAQ-II. CONCLUSION: BIPM-M is a psychometrically sound instrument that can be utilized to assess the psychological mindedness among Malaysians, and certainly enhance the array of psychological assessments available as Malaysia faces the mental health after-effect of COVID-19.

KEYWORDS: psychological mindedness, Balanced Index of Psychological Mindedness, Bahasa Malaysia, depressive symptoms

\section{INTRODUCTION}

The definition of psychological mindedness has been revised several times over the years, with the components involving awareness and understanding of psychological processes, such as thoughts, feelings, and behaviours. ${ }^{1}$ Some of the definitions focus more on self-awareness, which defined psychological mindedness as “A person's ability to

\section{Corresponding Author:}

Dr. Nicholas Pang Tze Ping,

Faculty of Medicine and Health Sciences,

Universiti Malaysia Sabah,

Jalan UMS, 88400 Kota Kinabalu,

Sabah, Malaysia

Tel No: +6016-8814058

Email : nicholas@ums.edu.my see relationships among thoughts, feelings, and actions, with the goal of learning the meanings and causes of his experiences and behaviour". ${ }^{2}$ Meanwhile, Gough (1969) proposed that psychologically minded individual as "interested in, and responsive to, the inner needs, motives, and experiences of others". 3 The more comprehensive definitions of psychological mindedness includes awareness of psychological processes in both self and others: "The disposition to reflect upon the meaning and motivation of behaviour, thoughts, and feelings of oneself and others". ${ }^{4}$ Building on these definitions, psychological mindedness involves the ability of a person to recognize meanings behind words and actions, to appreciate emotional overtone 
and complexity, identify between past and present, and insight into one's intentions. ${ }^{1,5}$ In other words, psychological mindedness is a persons' characteristic reflecting on both an attitude (interest) and skill (ability for insight). ${ }^{6}$ It is usually stable attribute of an individual, but it is modifiable, subject to significant external stimuli, such as major life events or psychotherapy.

It has previously been proven to be able to identify depressive symptoms of caregivers of people with autism spectrum disorders which is vital in addressing issues experienced by the caregivers so that a treatment plan can be made to help them. ${ }^{7}$ This is true for others who are experiencing depressive symptoms as well, despite being unable to properly express their feelings and emotions. This can lead to a negative impact to the person's life as they are usually found to cope with dysfunctional coping styles and have decreased ambiguity tolerance, personal agency, and lower propensity for reality-oriented thinking.

Previously there were few measurements of psychological mindedness available, such as the 22-item Psychological Mindedness scale of the California Personality Inventory, ${ }^{3}$ 45-item Psychological Mindedness Scale (PMS), ${ }^{8}$ and The Psychological Mindedness Assessment Procedure. However, the use of these measurements is limited in view of questionable content validity as well as being relatively time consuming. Therefore, the Balanced Index of Psychological Mindedness (BIPM) was introduced as an alternative psychological mindedness measurement, which showed excellent psychometric properties, as evidenced by good internal consistency (Cronbach's s alpha of 0.85 and 0.76 , respectively), test-retest reliability ( $\mathrm{r}=0.63$ and 0.71 , respectively), and construct validity (e.g., r $>0.40$ with related constructs). ${ }^{6}$ It is also brief, concise as well as easy to administer.

Generally Malaysian has a fairly good proficiency in English, especially in urban areas, being a multicultural and multilingual country. However, the same cannot be said to the majority of the middle -class socioeconomic population as well as rural communities which primarily speak in Bahasa Malaysia, the official language of Malaysia. ${ }^{10}$ To date, there are fairly limited validated psychological scale available in Bahasa Malaysia, such as BM-DASS-21 (Cronbach's alpha of 0.90) ${ }^{11}$ which focused on depression, anxiety and stress symptoms; Malay version Mindfulness, Attention and Awareness Scale (MMAAS) (Cronbach's alpha of 0.85$)^{12}$ which was used to objectively measure mindfulness, as well as Acceptance and Action Questionnaire-II (AAQ-II) (Cronbach's alpha of 0.91), ${ }^{13}$ to measure psychological inflexibility. Therefore, a psychological mindedness scale in the Bahasa Malaysia language is very much needed in order to help identify people with depressive symptoms.

\section{MATERIALS AND METHODS}

Consent to translate the scale from the original author was obtained. The study was conducted in 3 stages based on WHO instrument validation and translation guidelines.

\section{Stage 1:}

The Balanced Index of Psychological Mindedness (BIPM), was translated by appropriate individuals into the Bahasa Malaysia Language. Two individuals, one of whom was a language expert and one of whom was a content expert, translated it into Bahasa Malaysia. Subsequently, two individuals, one language and one content expert as well, back translated it into English. The four individuals subsequently convened as a panel to determine that the translations and back translations were suitable, which they then endorsed as the final translated version.

\section{Stage 2:}

Pilot testing was done with 50 Bahasa Malaysia speakers to confirm that the translated version was mutually intelligible with what they understood. All 50 participants were a mix of undergraduate students, nurses in a psychiatric clinic, and 
members of the general public. Any unsuitable words or phrases were then corrected after being identified. This yielded the final translated version of the Bahasa Malaysia BIPM (BIPM-M).

\section{Stage 3:}

The final translated version of BIPM-M was introduced in a validation study design. A sample of 141 individuals was used as the BIPM-M which contains 14 items, hence 140 was the minimum sample size for it to be statistically significant, using a ratio of 1 item: 10 respondents. ${ }^{14}$ The participants, mostly from university population, were recruited via convenience sampling method in view of the ongoing movement control order (MCO). There were around 270 students in the aforementioned faculty, hence there were 129 students who chose not to participate. All participants provided written informed consent for their participation.

The inclusion criteria were as follows:

Above 18 years of age.

Willing to participate in the study.

Able to read and converse fluently in Malay.

The study participants completed 4 separate questionnaires: a simple demographic questionnaire, Bahasa Malaysia version of BIPM, Bahasa Malaysia version of MAAS questionnaire as well as Bahasa Malaysia version of AAQ-II questionnaire. A brief questionnaire was used to record some relevant background information including age and gender. To comply with the social distancing and movement restrictions, participants were instructed to complete the questionnaires using Google forms by filling in the blanks and selecting one response that best described them.

\section{Ethics approval}

Ethics approval was obtained from the Medical Research Ethics Committee of Universiti Malaysia Sabah. There were no conflicts of interest to declare.

\section{RESULTS}

Table I shows the demographic variables of the participants. All continuous variables had skewness and kurtosis within the normal range. The majority of participants were female, single, were not quarantined, and were mostly in the agriculture course.

Table I The respondents' background information $(n=141)$

\begin{tabular}{llll}
\hline Background & Category & N & $\%$ \\
\hline \multirow{2}{*}{ Gender } & Male & 62 & $42.60 \%$ \\
& Female & 81 & $57.40 \%$ \\
& Secondary School & 114 & $80.90 \%$ \\
Level of Education & Bachelor's Degree & 26 & $18.40 \%$ \\
& Master Degree & 1 & $0.70 \%$ \\
Quarantine Status & Quarantined & 30 & $21.30 \%$ \\
& Not quarantined & 111 & $78.70 \%$ \\
& Single & 137 & $97.20 \%$ \\
Marital Status & Married & 3 & $2.10 \%$ \\
& Divorced & 1 & $0.70 \%$ \\
\hline
\end{tabular}

Principal component analysis was performed as KMO measure of sampling adequacy was 0.85, and Bartlett's test of sphericity was significant, suggesting they meet the criteria for factor analysis. Table II suggests that a two-factor model explains $56.56 \%$ of the variance, with the scree plot concurring as per Figure 1.

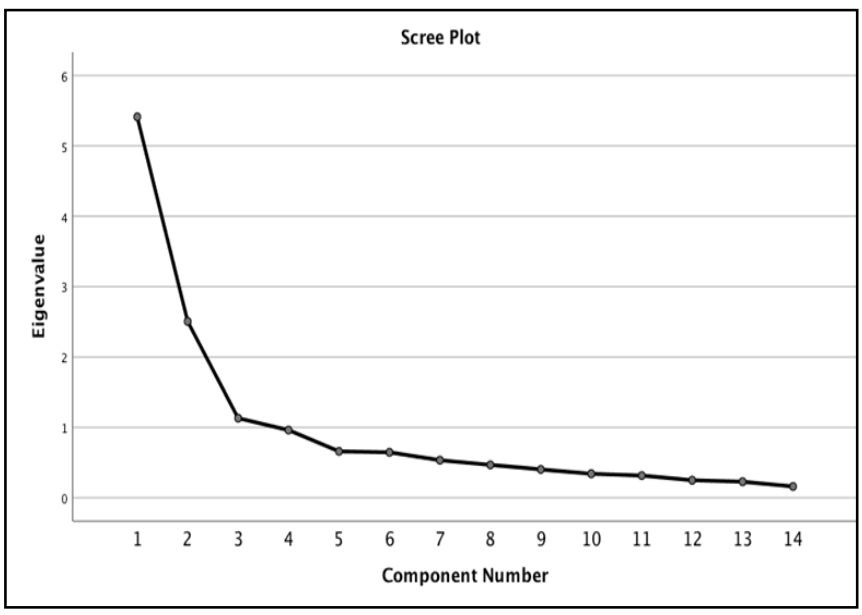

Figure 1 


\begin{tabular}{|c|c|c|c|c|c|c|c|}
\hline \multirow{2}{*}{ Component } & \multirow{2}{*}{ Total } & \multicolumn{2}{|c|}{ Initial Eigenvalues } & \multicolumn{3}{|c|}{$\begin{array}{c}\text { Extraction Sums of Squared } \\
\text { Loadings }\end{array}$} & \multirow{2}{*}{$\begin{array}{c}\begin{array}{c}\text { Rotation Sums } \\
\text { of Squared } \\
\text { Loadings }^{\mathbf{a}}\end{array} \\
\text { Total }\end{array}$} \\
\hline & & $\%$ of Variance & $\begin{array}{c}\text { Cumulative } \\
\%\end{array}$ & Total & $\begin{array}{c}\% \text { of } \\
\text { Variance }\end{array}$ & $\begin{array}{c}\text { Cumulative } \\
\%\end{array}$ & \\
\hline 1 & 5.41 & 38.66 & 38.66 & 5.41 & 38.66 & 38.66 & 4.93 \\
\hline 2 & 2.51 & 17.89 & 56.56 & 2.51 & 17.89 & 56.56 & 3.82 \\
\hline 3 & 1.13 & 8.07 & 64.63 & & & & \\
\hline 4 & 0.96 & 6.86 & 71.49 & & & & \\
\hline 5 & 0.66 & 4.70 & 76.19 & & & & \\
\hline 6 & 0.65 & 4.61 & 80.79 & & & & \\
\hline 7 & 0.53 & 3.80 & 84.60 & & & & \\
\hline 8 & 0.47 & 3.33 & 87.93 & & & & \\
\hline 9 & 0.40 & 2.87 & 90.79 & & & & \\
\hline 10 & 0.34 & 2.43 & 93.22 & & & & \\
\hline 11 & 0.31 & 2.25 & 95.47 & & & & \\
\hline 12 & 0.25 & 1.77 & 97.24 & & & & \\
\hline 13 & 0.23 & 1.62 & 98.87 & & & & \\
\hline 14 & 0.16 & 1.14 & 100.00 & & & & \\
\hline
\end{tabular}

Extraction Method: Principal Component Analysis

a. When components are correlated, sums of squared loadings cannot be added to obtain a total variance.

Table III demonstrates the pattern matrix between the components of the BIPM. Although two questions overlap into two different factors, the correlations for the weaker factor ranges from 0.31 -0.32 , which is barely above the exclusion cut-off correlation of 0.30 . Hence, it appears that they have borderline correlations. If so, the 14 items of the BIPM-M cleanly separate into two factors.

T-tests suggested that there was no significant difference between gender and quarantine status for BIPM-M, BIPM-E, and AAQ-II scores.

Table III also shows the reliability estimates for the BIPM. As suggested, reliability on all three methods (McDonald's omega, greatest lower bound, and Cronbach's alpha) all exceeded 0.70, with ranges between 0.87-0.95. The Cronbach alpha for the Insight and Interest subscales was 0.87 and 0.82 respectively.

Oblimin rotation with Kaiser normalization was performed in the analysis. From the initial free analysis, 3 factors were found. However, as the scree plot suggested, decision was made to omit the 3rd factor as it did not really explain any better than the 2 factors.
Subsequently, upon force analysis, it was found that the 2-factor model has minimal overlap, while the 3-factor model has too many overlaps.

Table IV shows the correlations between the BIPM and other relevant scales. It was moderately correlated with the AAQ-II scale ( $r=-0.36)$, suggesting acceptable concurrent validity. Correlations between the full BIPM-M scale were also established with the BIPM Insight (0.66) and Interest (0.44) subscale. Insight $(-0.72)$ and Interest $(0.42)$ were also correlated with psychological flexibility.

\section{DISCUSSION}

Psychological mindedness is an essential construct in assessing the abilities of people to be inquisitive about the thought processes of themselves and others. In this sense it can be associated with psychological flexibility. This is because the ability to drop the struggle with one's own thoughts, and also the ability to unhook from distressing thoughts, presupposes being aware of those thoughts and feelings. ${ }^{15}$ Psychological mindedness 


\begin{tabular}{|c|c|c|}
\hline & \multicolumn{2}{|c|}{ Component } \\
\hline & $\begin{array}{c}1 \\
\text { (Interest) }\end{array}$ & $\begin{array}{c}2 \\
\text { (Insight) }\end{array}$ \\
\hline $\begin{array}{l}\text { 1. I am often not aware of my feelings. } \\
\text { (Saya kerap kali tidake menyedari perasaan saya.) }\end{array}$ & 0.86 & \\
\hline $\begin{array}{l}\text { 2. My attitude and feelings about things fascinate me. } \\
\text { (Sikap dan perasaan saya terbadap sesuatu perkara dapat menarik perbatian saya.) }\end{array}$ & & 0.75 \\
\hline $\begin{array}{l}\text { 3. Most of the time, I experience little or no emotion. } \\
\text { (Kebanyakan masanya, saya mengalami sedikit atau tidak mengalami emosi.) }\end{array}$ & 0.43 & \\
\hline $\begin{array}{l}\text { 4. I guess I rarely listen to my feelings. } \\
\text { (Saya rasa bahawa saya jarang mempedulikan perasaan saya.) }\end{array}$ & 0.71 & \\
\hline $\begin{array}{l}\text { 5. My negative feelings can teach me a lot about myself. } \\
\text { (Perasaan negatif saya banyak mengajar saya tentang diri sendiri.) }\end{array}$ & 0.31 & 0.48 \\
\hline $\begin{array}{l}\text { 6. I don't know what's going on inside me. } \\
\text { (Saya tidak tabu apa yang berlaku dalam diri saya.) }\end{array}$ & 0.86 & \\
\hline $\begin{array}{l}\text { 7. In the end you're better off when taking seriously also your negative } \\
\text { feelings. } \\
\text { (Kita akan rasa lebih baik sekiranya kita mengambil kira perasaan negatif dalam diri } \\
\text { kita dengan serius.) }\end{array}$ & 0.32 & 0.43 \\
\hline $\begin{array}{l}\text { 8. My feelings show me what I need. } \\
\text { (Perasaan saya menunjukkan kepada saya apa yang saya perlu.) }\end{array}$ & & 0.79 \\
\hline $\begin{array}{l}\text { 9. I am out of touch with my innermost feelings. } \\
\text { (Saya kurang memabami perasaan saya yang paling mendalam.) }\end{array}$ & 0.89 & \\
\hline $\begin{array}{l}\text { 10. I never think about what made me act in a certain way. } \\
\text { (Saya tidak pernab memikirkan apa yang menyebabkan saya bertindak dalam cara } \\
\text { yang tertentu.) }\end{array}$ & 0.74 & \\
\hline $\begin{array}{l}\text { 11. I am better off when being in touch with my feelings. } \\
\text { (Saya rasa adalab lebih baik sekiranya saya memabami perasaan saya sendiri.) }\end{array}$ & & 0.70 \\
\hline $\begin{array}{l}\text { 12. I can't make sense out of my feelings. } \\
\text { (Saya tidak dapat memahami perasaan saya.) }\end{array}$ & 0.90 & \\
\hline $\begin{array}{l}\text { 13. I love exploring my "inner" self. } \\
\text { (Saya suka menerokai diri dalaman saya.) }\end{array}$ & & 0.70 \\
\hline $\begin{array}{l}\text { 14. My deeper feeling is a good advisor. } \\
\text { (Perasaan dalaman saya ialab penasibat yang baik.) }\end{array}$ & & 0.82 \\
\hline Psychometric Properties via CTT Method & Result & $\begin{array}{l}\text { Suggested Cut- } \\
\text { off }\end{array}$ \\
\hline Internal consistency measure using Cronbach's alpha & 0.87 & $>0.70$ \\
\hline Internal consistency measure using McDonald's omega & 0.88 & $>0.70$ \\
\hline Internal consistency measure using Greatest lower bound & 0.95 & $>0.70$ \\
\hline
\end{tabular}

- Extraction Method: Principal Component Analysis Rotation Method: Oblimin with Kaiser Normalization. ${ }^{\mathrm{a}}$

- *Correlation is significant at the 0.05 level (two-tailed test) ** Correlation is significant at the 0.01 level (two-tailed test)

Note: Correlation coefficients of $<0.25$ were considered as small; $0.25-0.50$ as moderate; $0.50-0.75$ as good; and $>0.75$ as excellent

also appears inextricably associated with general symptoms. ${ }^{16,17}$ Furthermore, studies have supported psychological wellness, which links in to research that psychological mindedness is beneficial to suggesting that psychological mindedness is physical functioning as well, as it implies awareness associated with lower levels of psychopathology, of individual's internal psychological states, signals and can even mediate the relationship between and needs, thus leading to appropriate action. ${ }^{18}$ dysfunctional coping styles and depressive 


\begin{tabular}{|c|c|c|c|c|c|c|}
\hline & & $\begin{array}{c}\text { Malay BIPM } \\
\text { Score }\end{array}$ & InsightM & InterestM & MAAS Score & $\begin{array}{l}\text { AAQ-II } \\
\text { Score }\end{array}$ \\
\hline \multirow[t]{2}{*}{$\begin{array}{c}\text { Malay BIPM } \\
\text { Score }\end{array}$} & $\begin{array}{c}\text { Pearson } \\
\text { Correlation }\end{array}$ & 1 & $0.66^{* *}$ & $0.44 * *$ & 0.09 & $-0.36^{* *}$ \\
\hline & Sig. (2-tailed) & & 0.00 & 0.00 & 0.28 & 0.00 \\
\hline \multirow[t]{2}{*}{ InsightM } & $\begin{array}{l}\text { Pearson } \\
\text { Correlation }\end{array}$ & $0.066^{* *}$ & 1 & $-0.39 * *$ & 0.05 & $-0.72^{* *}$ \\
\hline & Sig. (2-tailed) & 0.00 & & 0.00 & 0.56 & 0.00 \\
\hline \multirow[t]{2}{*}{ InterestM } & $\begin{array}{l}\text { Pearson } \\
\text { Correlation }\end{array}$ & $0.44 * *$ & $-0.39 * *$ & 1 & 0.05 & $0.42 * *$ \\
\hline & Sig. (2-tailed) & 0.00 & 0.00 & & 0.53 & 0.00 \\
\hline \multirow[t]{2}{*}{ MAAS Score } & $\begin{array}{l}\text { Pearson } \\
\text { Correlation }\end{array}$ & 0.09 & 0.05 & 0.05 & 1 & -0.01 \\
\hline & Sig. (2-tailed) & 0.28 & 0.56 & 0.53 & & 0.92 \\
\hline \multirow[t]{2}{*}{ AAQ-II Score } & Pearson Correlation & $-0.36 * *$ & $-0.72^{* *}$ & $0.42^{* *}$ & -0.01 & 1 \\
\hline & Sig. (2-tailed) & 0.00 & 0.00 & 0.00 & 0.92 & \\
\hline
\end{tabular}

**. Correlation is significant at the 0.01 level $(2-$ tailed $)$.

This study also further confirms the factorial model of the BIPM, and by extension the construct of psychological mindedness, as a twofactor model incorporating Interest and Insight. This correlates with other recent validations in German, ${ }^{19}$ and also a study in caregivers of autism. ${ }^{7}$ Interestingly however, the correlations were in opposite directions; the more insight one had, the more psychologically flexible one was, whereas the more interest one had, the less psychologically flexible one was. This varies slightly with the German validation where only Insight but not Interest was correlated positively with psychological flexibility. One possible reason the Malaysian version showed divergent results was that there are cultural differences in that Malaysian belongs to a more collectivist culture. Hence, there may be less focus on understanding and responding to one's psychological processes and others in favour of statements that are more reflective of the opinions of the general majority. ${ }^{20,21}$ Thus, there may be lower levels of psychological flexibility in Malaysian populations, and there is then a knock-on effect on lower interest in PM in the Malaysian context.

This study nevertheless has certain limitations. The study was performed in a university student population, which may limit its generalizability into clinical settings where it is most essential to measure PM. Hence, once a validation is published, it may be crucial to perform further validations in clinical populations in order to ascertain its properties remain intact. Additionally, the sample size also certainly could be improved. Apart from that, this study was also hampered by having to use online platforms due to it being done in the midst of social distancing rules of COVID-19. This might have created small amounts of response bias, but there is little evidence suggesting that online forms actually do so in university students. ${ }^{22}$

\section{CONCLUSION}

BIPM-M has appeared to be fairly robust psychometrically as an exciting new scale in measuring the levels of psychological mindedness, which is emerging as a promising psychological process variable. By validating the BIPM into Malay, it allows far stronger studies to be performed which can examine complex mediational relationships and ascertain the effect of psychotherapies in experimental studies in a study population that is more reflective of the Malaysian population at large. As Malaysia faces the consequence of COVID-19, which is currently in the more serious third wave, mental health is bound to be greatly affected. It is thus hoped that BIPM-M could contribute to ascertain mental health condition of Malaysians. 


\section{CONFLICT OF INTEREST}

All authors declared no conflict of interest.

\section{ACKNOWLEDGEMENT}

This study received research grant funding under Special Fund Scheme Universiti Malaysia Sabah (SDK0195 - 2020).

\section{REFERENCES}

1. Beitel M, Ferrer E, Cecero JJ. Psychological mindedness and awareness of self and others. J Clin Psychol. 2005; .doi:10.1002/jclp.20095

2. Appelbaum SA. Psychological mindedness: word, concept and essence. Int J Psychoanal. 1973; .doi:https://psycnet.apa.org/record/1974-11508001

3. Gough HG. Manual for the California Psychological Inventory. Palo Alto, California: Consulting Psychologists Press; 1969.

4. Farber BA. The genesis, development, and implications of psychological- mindedness in psychotherapists. Psychotherapy. 1985; .doi:10.1037/h0085490

5. Conte HR, Ratto R. Psychological mindedness : a contemporary understanding. In: McCallum M, Piper WE, editors. The LEA series in personality and clinical psychology. Lawrence Erlbaum Associates Publishers.; 1997. p. 21.

6. Nykliček I, Denollet J. Development and evaluation of the Balanced Index of Psychological Mindedness (BIPM). Psychol Assess. 2009;21 (1):32-44. .doi:10.1037/a0014418

7. Pang NTP, Masiran R, Tan K-A, Kassim A. Psychological mindedness as a mediator in the relationship between dysfunctional coping styles and depressive symptoms in caregivers of children with autism spectrum disorder. Perspect Psychiatr Care. 2020; .doi:doi.org/10.1111/ppc.12481

8. Conte HR, Plutchik R, Jung BB, Picard S, Karasu TB, Lotterman A. Psychological Mindedness as a predictor of psychotherapy outcome: A preliminary report. Compr Psychiatry. 1990; .doi:10.1016/0010-440X(90)90027-P

9. McCallum M, Piper WE. The Psychological Mindedness Assessment Procedure. Psychol
Assess. 1990; .doi:10.1037/1040-3590.2.4.412

10. Azman H. English Language in Malaysia: Situating Global Literacies in Local Practises. 3L Lang Linguist Lit. 2006;11. .doi:https:/ / core.ac.uk/ reader/11490316

11. Musa R, Fadzil MA, Zain Z. Translation, validation and psychometric properties of Bahasa Malaysia version of the Depression Anxiety and Stress Scales (DASS). ASEAN J Psychiatry. 2007;8(2):82-9. .doi:https:// www.ramlimusa.com/wp-content/ uploads/2.DASS_Musa_1_070917.pdf

12. Zainal NZ, Nor-Aziyan Y, Subramaniam P. Psychometric properties of the Malay-translated Mindfulness, Attention and Awareness Scale (MAAS) in a group of nursing students in Malaysia. Malaysian J Psychiatry. 2015;24(1). .doi:https://www.mjpsychiatry.org/index.php/ $\mathrm{mjp} /$ article/view/352

13. Shari NI, Zainal NZ, Guan NC, Sabki ZA, Yahaya NA. Psychometric properties of the acceptance and action questionnaire (AAQ II) Malay version in cancer patients. PLoS One. 2019; .doi:10.1371/journal.pone.0212788

14. Everitt BS. Multivariate analysis: the need for data, and other problems. Br J Psychiatry. 1975; .doi:10.1192/bjp.126.3.237

15. Giromini L, Brusadelli E, Di Noto B, Grasso R, Lang M. Measuring psychological mindedness: validity, reliability, and relationship with psychopathology of an Italian version of the Balanced Index of Psychological Mindedness. Psychoanal Psychother. 2015; .doi:10.1080/02668734.2015.1006666

16. Beitel M, Cecero JJ. Predicting psychological mindedness from personality style and attachment security. J Clin Psychol. 2003; .doi:10.1002/ jclp.10125

17. Nykliček I, Poot JC, van Opstal J. Psychological mindedness in relation to personality and coping in a sample of young adult psychiatric patients. J Clin Psychol. 2010;66(1):34-45. .doi:10.1002/ jclp.20627

18. Shill MA, Lumley MA. The Psychological Mindedness Scale: Factor structure, convergent validity and gender in a non-psychiatric sample. Psychol Psychother Theory, Res Pract. 2002; .doi:10.1348/147608302169607 
19. Krupp J, Liesen L, Hamburger A. Balanced Index of Psychological Mindedness (BIPM). Z

Psychosom Med Psychother. 2020; .doi:10.13109/ zptm.2020.66.2.164

20. Caldwell-Harris CL, Ayçiçegi A. When Personality and Culture Clash: ThE Psychological Distress of Allocentrics in an Individualist Culture and Idiocentrics in a Collectivist Culture. Transcult Psychiatry. 2006; .doi:10.1177/1363461506066982

21. Tafarodi RW, Smith AJ. Individualism-

collectivism and depressive sensitivity to life events: : the case of Malaysian sojourners. Int J Intercult Relations. 2001; .doi:10.1016/S01471767(00)00043-2 